\title{
Dietary Fiber Inclusion as an Alternative to Feed Fasting to Induce Molting in Commercial Layers
}

\section{-Author(s)}

Sgavioli S

Filardi R da $\mathrm{S}^{\mathrm{II}}$

Praes M F F M'

Domingues $\mathrm{C} \mathrm{H}$ de $\mathrm{F}^{\prime}$

Pileggi J'

Andrade $\mathrm{P}$ de $\mathrm{C}^{\mathrm{I}}$

Boleli I C'

Junqueira $\mathrm{O} M$

Universidade Estadual Paulista Júlio de Mesquita Filho, Jaboticabal, SP.

" Universidade Estadual Paulista Júlio de Mesquita Filho, Ilha Solteira, SP.

\section{ABSTRACT}

The objective of the present experiment was to compare the performance, egg quality and organ morphometrics of commercial layers submitted to alternative forced molting methods using dietary fibers. The experimental period included the phases of molting, rest, and second laying cycle (six periods of 28 days each). In the trial, 320 commercial Isa Brown layers with 72 weeks of age were distributed, according to a completely randomized experimental design into five treatments with eight replicates of eight birds each, totaling 40 experimental units. Molting was induced by feeding diets with the inclusion of alfalfa or soybean husks at $80 \%$ and $60 \%$ or feed fasting. Treatments were applied for 14 days. Performance and egg quality parameters were evaluated for the second laying cycle and organ morphometrics (liver, gizzard, proventriculus, reproductive apparatus) in two different slaughter dates. The obtained data were submitted to analysis of variance using the General Linear Model (GLM) procedure of SAS statistical package (SAS Institute, 2002). Alternative molting methods promoted similar performance and egg quality results after molting were similar to those obtained by the conventional fasting method. Feeding fiber produced the expected effects in terms of organ weight regression and recovery and may be used to induce molting in commercial layers.

\section{INTRODUCTION}

The technical development and the high revenues place the poultry industry in the forefront of animal production. Some practices applied in the egg industry have been in the center of the controversies between animal rights groups, consumers, farmers, and researchers. One of these practices is forced molting (Berry, 2003), which is used to increase the productive life of layers and to maintain their performance levels.

There are many forced molting methods, but the most common is feed fasting, which is strongly criticized by animal welfare organizations (Bell \& Kuney, 2004).

The feed fasting method consists in submitting hens to long fasting periods that, despite producing satisfactory results and being easy to apply, results in severe stress. Taking into consideration these welfare issues, other methods have been proposed. For instance, feeding fiberrich diets reduces the stress caused by fasting (Koelkebeck et al., 1992), and has the same expected effects, that is, hens stop laying, allowing for the recovery of the reproductive tract, but start the second laying cycle faster than those fasted.

Some of the alternative feedstuffs used to induce molting are alfalfa hay (Kwon et al., 2001; Donalson et al., 2005; Landers et al., 2005; Sgavioli et al., 2011) and soybean husks (Girardon, 2011). These 
ingredients induce the perception of satiety due to their high fiber content or low palatability (Sibbald, 1979). Moreover, the use of these feedstuffs is not limited by cost, as with other techniques; however, there are few studies on literature on their application to induce molting.

Therefore, the present study aimed at evaluating the use of dietary as an alternative forced-molting method on the performance, egg quality, and organ morphometrics of commercial layers.

\section{MATERIALS AND METHODS}

The experimental period included the phases of molting, rest, and second laying cycle (six periods of 28 days each). Birds were selected by body weight and egg production, and were then housed in a conventional layer house during the entire experimental period.

In the trial, 320 commercial Isa Brown layers with 72 weeks of age were distributed, according to a completely randomized experimental design into five treatments with eight replicates of eight birds each, totaling 40 experimental units.

During the molting period, a lighting program of $12 \mathrm{~h}$ of light per day was adopted, and the period was light was gradually increased during the resting period until 17 hours of light per day, which was applied during the second production cycle. During the resting period and the second production cycle, birds were offered feed and water ad libitum.

The following five methods were applied to induce molting: $80 \%$ alfalfa and 20\% feed (A80); $60 \%$ alfalfa and $40 \%$ feed (A60); $80 \%$ soybean hulls and $20 \%$ feed (CS80); 60\% soybean hulls and 40\% feed (CS60) and feed fasting (control).

During the second production cycle, the following performance parameters were evaluated at the end of each period: feed intake, egg production, average egg weight (total weight of eggs laid divided by the number of eggs laid per experimental unit), egg mass (egg production percentage multiplied by average

Table 1 - Calculated nutritional composition of the experimental feeds supplied during the different experimental phases.

\begin{tabular}{|c|c|c|c|c|c|c|}
\hline & \multicolumn{4}{|c|}{ Molting method* } & \multirow[t]{2}{*}{ Resting } & \multirow[t]{2}{*}{ Second laying cycle } \\
\hline & A80 & A60 & CS80 & CS60 & & \\
\hline Metabolizable energy (kcal/kg) & 1.184 & 1.592 & 2.000 & 3.025 & 3.008 & 2.800 \\
\hline Crude protein (\%) & 17.00 & 17.00 & 17.00 & 17.00 & 17.00 & 17.00 \\
\hline Crude fiber (\%) & 22.82 & 18.45 & 14.09 & - & - & - \\
\hline Calcium (\%) & 1.270 & 1.210 & 1.150 & 1.020 & 1.020 & 4.200 \\
\hline Available phosphorus (\%) & 0.110 & 0.170 & 0.230 & 0.380 & 0.380 & 0.380 \\
\hline Total phosphorus (\%) & 0.267 & 0.341 & 0.415 & 0.603 & 0.602 & 0.591 \\
\hline Sodium (\%) & 0.077 & 0.071 & 0.065 & 0.050 & 0.230 & 0.230 \\
\hline Total lysine (\%) & 0.796 & 0.808 & 0.820 & 0.855 & 0.856 & 0.892 \\
\hline Dig. Lysine (\%) & 0.595 & 0.645 & 0.695 & 0.816 & 0.818 & 0.859 \\
\hline Total methionine (\%) & 0.264 & 0.292 & 0.320 & 0.389 & 0.390 & 0.399 \\
\hline Dig. methionine (\%) & 0.218 & 0.254 & 0.290 & 0.376 & 0.377 & 0.390 \\
\hline Total met+cys (\%) & 0.466 & 0.518 & 0.570 & 0.698 & 0.698 & 0.698 \\
\hline Dig. met+cys (\%) & 0.428 & 0.484 & 0.540 & 0.680 & 0.680 & 0.680 \\
\hline Total threonine & 0.733 & 0.718 & 0.703 & 0.658 & 0.658 & 0.658 \\
\hline Dig. threonine (\%) & 0.630 & 0.490 & 0.350 & 0.570 & 0.570 & 0.572 \\
\hline Total tryptophan (\%) & 0.258 & 0.234 & 0.210 & 0.151 & 0.151 & 0.166 \\
\hline Dig. tryptophan (\%) & 0.230 & 0.210 & 0.190 & 0.137 & 0.137 & 0.150 \\
\hline
\end{tabular}

${ }^{*} \mathrm{~A} 80=80 \%$ alfalfa and $20 \%$ feed; $A 60=40 \%$ alfalfa; CS80 = $80 \%$ soybeans hulls and $20 \%$ feed; CS60 $=40 \%$ soybeans hulls ans $30 \%$ feed. 
egg weight), eggshell percentage (ratio between shell weight and egg weight), and feed conversion ratio (kg feed per kg eggs and per dozen eggs). Egg quality was also evaluated as to: Haugh unit (100 log $(h+7.57-$ 1.7 W 0,37), where: $\mathrm{H}=$ albumen height in $\mathrm{mm}, \mathrm{W}=$ egg weight in $\mathrm{g}$, and egg specific gravity (using $\mathrm{NaCl}$ solutions with densities between 1.065 and $1.100 \mathrm{~g} /$ $\mathrm{cm}^{3}$, at 0.005 gradients, according to Moreng \& Avens, 1990).

During the experimental period, four birds per treatment were sacrificed after the molting process was completed, and four after resting in order to determine relative liver, proventriculus, gizzard, and reproductive apparatus weights. Mortality was daily recorded during the entire experimental period.

Feeds were based on corn and soybean meal, and formulated according to the recommendations of Rostagno et al. (2005) as shown in Table 1.

The obtained data were submitted to analysis of variance using the General Linear Models (GLM) procedure of SAS® statistical package (SAS Institute, 2002). When effect was significant, means were compared, at $5 \%$ probability level, by orthogonal contrasts: Contrast 1 - comparison of the average of the treatments with alfalfa inclusion with the average of the treatments with soybean hulls inclusion; contrast 2 - comparison of the average of the treatments with fiber inclusion with the feed fasting; contrast 3 - comparison between treatments with 80 or $60 \%$ alfalfa inclusion; and contrast 4 - comparison between treatments with 80 or $60 \%$ soybean hulls inclusion.

\section{RESULTS AND DISCUSSION}

The different methods used to induce molting did not influence layer performance during the second laying cycle (Table 2). The high concentration of indigestible fibers present in soybeans hulls and alfalfa hay may restrict nutrient availability, but result in a perception of satiety, due to the presence of saponins (Sibbald, 1979). Nevertheless, no effect of the dietary treatments applied during molting on feed intake ( $p>0.05)$ was observed in the present experiment, suggesting that the treatments did not cause any permanent adverse effect on layer performance. These results are consistent with the findings of Biggs et al. (2004) and Sgavioli et al. (2011), who evaluated alternative molting methods by feeding fiber, wheat and alfalfa, and did not observe any effect on layer performance during their second cycle of lay.

However, Mejia et al. (2010) fed layers with distiller's dry grain with solubles (2010), soybean hulls or wheat midds during molting, and found lower egg weight in the hens fed $47 \%$ soybean hulls.

In the study of Girardon (2011), the best egg mass and relative egg production were obtained when the molting methods applied were $100 \%$ soybean hulls and feed fasting, respectively. That author also mentioned that, when considering the results related to stress, soybean hulls are better than feed fasting to induce molting. Onbasilar \& Erol (2007) also observed layers submitted to induced molting by feed fasting had higher relative egg production.

Table $\mathbf{2}$ - Layer performance during the second laying cycle

\begin{tabular}{|c|c|c|c|c|c|c|}
\hline Treatments & Feed intake & $\begin{array}{c}\text { Relative } \\
\text { production }\end{array}$ & Egg weight & Egg mass & $\begin{array}{c}\text { Feed conversion } \\
\text { ratio }\end{array}$ & $\begin{array}{c}\text { Feed conversion } \\
\text { ratio }\end{array}$ \\
\hline & (g/hen/d) & (\%/hen/d) & (g) & $(g / d)$ & $(\mathrm{kg} / \mathrm{dz})$ & $(\mathrm{kg} / \mathrm{kg})$ \\
\hline $80 \%$ alfalfa & 105.04 & 81.53 & 70.52 & 57.54 & 1.57 & 1.86 \\
\hline $60 \%$ alfalfa & 104.34 & 75.76 & 72.92 & 54.94 & 1.73 & 1.98 \\
\hline $80 \%$ soybean hulls & 102.07 & 74.41 & 73.49 & 54.71 & 1.67 & 1.90 \\
\hline $60 \%$ soybean hulls & 102.17 & 65.94 & 69.20 & 45.65 & 1.92 & 2.33 \\
\hline Feed fasting & 104.03 & 72.74 & 68.88 & 50.12 & 1.77 & 2.15 \\
\hline Probability & $0.7328^{\mathrm{NS}}$ & $0.2238^{\mathrm{NS}}$ & $0.1519^{N S}$ & $0.1945^{\text {NS }}$ & $0.2429^{\mathrm{NS}}$ & $0.1447^{\mathrm{NS}}$ \\
\hline CV (\%) & 3.64 & 11.97 & 4.24 & 13.60 & 12.20 & 13.67 \\
\hline
\end{tabular}

Ns - not significant. CV - coefficient of variation 
Sgavioli S, Filardi R da S, Praes M F F M, Domingues C H de F, Pileggi J, Andrade P de C, Boleli I C,

Junqueira $\mathrm{O} M$

The evaluated molt induction methods did not influence ( $p>0.05$ ) egg quality parameters during the second laying cycle (Table 3). In addition, there was no effect of molting method on eggshell percentage during the second laying cycle. This is consistent with the results of Giampaulli et al. (2005), who obtained $8.96 \%$ eggshell in the eggs of layers submitted to feed fasting for 10 days.

Table 3 - Egg quality during the second laying cycle

\begin{tabular}{lccc}
\hline Treatments & Haugh units & Eggshell (\%) & $\begin{array}{c}\text { Egg specific } \\
\text { gravity }\left(\mathrm{g} / \mathrm{cm}^{3}\right)\end{array}$ \\
\hline $80 \%$ alfalfa & 84.38 & 8.65 & 1.084 \\
\hline $60 \%$ alfalfa & 81.24 & 8.69 & 1.081 \\
\hline $80 \%$ soybean hulls & 84.85 & 8.75 & 1.083 \\
\hline $60 \%$ soybean hulls & 84.01 & 8.68 & 1.083 \\
\hline Feed fasting & 85.97 & 8.57 & 1.083 \\
\hline Probability & $0.4505^{\mathrm{NS}}$ & $0.9780 \mathrm{~ns}$ & $0.8183^{\mathrm{NS}}$ \\
$\begin{array}{l}\text { Coefficient of variation } \\
\text { (\%) }\end{array}$ & 4.23 & 4.59 & 0.27 \\
\hline
\end{tabular}

Ns - not significant.

Other studies (Landers et al., 2005) also report that that egg quality during the second laying cycle was not different when molting was induced by feed fasting or by feeds containing alfalfa hay. In the study of Girardon (2011), however, the best Haugh unit and egg specific gravity were obtained when the molting methods applied were 100\% soybean hulls and feed fasting, respectively.

Some authors (Donalson et al., 2005; Sgavioli et al., 2011) evaluated the feed inclusion of increasing alfalfa levels to induce molting, and observed a linear and negative effect on Haugh units. Those authors suggested that internal egg quality is impaired by increasing dietary fiber levels during molting, differently from the findings of the present study.

Ovary weight loss is simultaneous to body weight loss, and this process is directly linked to the recovery of the hen's reproductive tract during the molting period (Braker, 1983). Souza et al. (2010) reported that many studies in literature found that reproductive tract involution during forced molting is required to ensure adequate performance during the second laying cycle. Therefore, morphometric characteristics of some organs of the hens submitted to molting were determined (Tables 4 and 5).

The low feed intake, stress, and nutritional unbalance that result in the involution of the reproductive tract cause a cascade of neuroendocrine effects. Feed fasting or the provision of feeds, which
Dietary Fiber Inclusion as an Alternative to Feed Fasting to Induce Molting in Commercial Layers

composition does not supply the nutrients required for body maintenance, cause stress and, consequently hypothalamus hyperactivity. The hypothalamus then releases corticotropic (ACTHRF) and thyrotropic (TSHRF) hormones (Girardon, 2011), influencing the pituitary, which then starts secreting ACTH and TSH. The increase in the blood levels of these hormones leads to adrenal and thyroid hypertrophy and hyperfunction, causing gonadotropic hormone unbalance (Garcia, 2004).

Table 4 - Relative organ weights when layers were sacrificed post-molting.

\begin{tabular}{|c|c|c|c|c|}
\hline \multirow[t]{2}{*}{ Treatments } & Liver & Proventriculus & $\begin{array}{c}\text { Reproductive } \\
\text { tract }\end{array}$ & Gizzard \\
\hline & \multicolumn{4}{|c|}{ (\%) } \\
\hline $80 \%$ alfalfa & 2.16 & 0.31 & 6.43 & 1.52 \\
\hline $60 \%$ alfalfa & 2.02 & 0.44 & 6.39 & 1.54 \\
\hline $\begin{array}{l}80 \% \text { soybean } \\
\text { hulls }\end{array}$ & 2.76 & 0.41 & 6.87 & 1.37 \\
\hline $\begin{array}{l}60 \% \text { soybean } \\
\text { hulls }\end{array}$ & 2.12 & 0.37 & 6.59 & 1.63 \\
\hline Feed fasting & 2.59 & 0.37 & 5.81 & 1.61 \\
\hline Probability & $\begin{array}{c}0.4218 \\
\text { ns }\end{array}$ & 0.5291 NS & $0.7375^{\mathrm{NS}}$ & $\begin{array}{c}0.4042 \\
\text { NS }\end{array}$ \\
\hline CV (\%) & 18.08 & 18.22 & 12.01 & 8.61 \\
\hline
\end{tabular}

NS - not significant. CV - coefficient of variation

The relative weight of the reproductive tract (ovary + oviduct) was not influenced $(p>0,05)$ by the tested molting induction method on none of the sacrifice dates. Consistent results were obtained by Landers et al. (2005), Woodward et al. (2005), and Freitas et al. (2011), when feeding hens with different percentages of alfalfa and white leadtree (Leucaena leucocephala) hay to induce molting. Araújo et al. (2007) evaluated feed fasting and diets with high zinc, low calcium, and low sodium levels to induce molting and also did not find any effect on reproductive tract weight.

Table 5 - Relative organ weights when layers were sacrificed post-resting.

\begin{tabular}{|c|c|c|c|c|}
\hline \multirow{2}{*}{ Treatments } & Liver & Proventriculus & Reproductive tract & Gizzard \\
\hline & \multicolumn{4}{|c|}{$(\%)$} \\
\hline $80 \%$ alfalfa & 1.79 & 0.33 & 6.67 & 1.14 \\
\hline $60 \%$ alfalfa & 2.19 & 0.29 & 6.31 & 1.19 \\
\hline $\begin{array}{l}80 \% \text { soybean } \\
\text { hulls }\end{array}$ & 1.87 & 0.33 & 7.51 & 1.19 \\
\hline $\begin{array}{l}60 \% \text { soybean } \\
\text { hulls }\end{array}$ & 2.24 & 0.37 & 5.65 & 1.27 \\
\hline Feed fasting & 2.42 & 0.31 & 7.25 & 1.25 \\
\hline Probability & $\begin{array}{c}0.6453 \\
\text { NS }\end{array}$ & $0.8202^{\text {NS }}$ & $0.4615^{\mathrm{NS}}$ & $\begin{array}{c}0.9504 \\
\text { NS }\end{array}$ \\
\hline CV (\%) & 22.11 & 18.29 & 15.26 & 15.75 \\
\hline
\end{tabular}

Ns - not significant. CV - coefficient of variation 
On the other hand, Sgavioli (2010) observed lower reproductive tract weight loss when layers were fed $50 \%$ alfalfa hay compared with 90 and $70 \%$ alfalfa hay in the feed. Therefore, the results of the present study and literature findings corroborate with the idea that high dietary fiber supply to induce molting in layers causes similar reproductive tract weight loss as feed fasting.

According to Landers et al. (2005), in order to be accepted by the poultry industry, methods to induce molting must provide a stimulus substantial enough to cause sufficient reproductive tract regression during molting and result in egg production and quality in the second cycle similar to those obtained with the feed fasting method.

There were no changes $(p>0,05)$ in the other organs evaluated post-molting. These results are consistent with the findings of Sgavioli (2010), who also did not observe any influence of different dietary alfalfa inclusion levels on gizzard, liver, or proventriculus weights.

Souza et al. (2010) evaluated different feed restriction levels and observed that the highest relative gizzard weight (3.07\%) was obtained in layers submitted to $50 \%$ feed restriction, whereas the most severe gizzard weight reduction was obtained with feed fasting. When low fiber inclusion was used by the authors to induce molting, reproductive organ regression was not efficient. In the present study, however, the weight loss of the gizzard, proventriculus, and liver obtained with the high alfalfa hay and soybean hull levels was similar to that obtained with feed fasting.

There are few reports in literature on the induction of molting in layers using alternative feedstuffs, particularly soybean hulls. This study showed that both soybean hulls and alfalfa hay can be used with the same efficiency as feed fasting to induce molting in commercial layers. However, their mode of action is not fully elucidated.

The results of the present study indicate that layers submitted to induced molting by dietary fiber inclusion presented similar reproductive tract regression and recovery as those submitted to feed fasting, but were less stressed due to feed supply. Therefore, the low nutrient supply of the treatments with high fiber inclusion did not cause any irreversible damage to the layers' reproductive tract, as shown by their relative egg production during the second laying cycle (Table 2).

\section{CONCLUSIONS}

The results of the present study indicate that dietary fiber can be used to induce molting in commercial layers, as shown by the similar performance and egg quality results during the second laying cycle compared with those obtained with conventional feed fasting, demonstrating that there was proper regression and recovery of the reproductive organs. Therefore, induced molting methods with dietary fiber inclusion may be used as an alternative to feed fasting, obtaining similar results in the second laying cycle.

\section{REFERENCES}

Araújo CSS, Baraldi-artoni SM, Araújo LF, Junqueira OM, Barbosa LCGS, Lima CG. Morfometria do oviduto de poedeiras comerciais semipesadas submetidas a diferentes métodos de muda. Ciência Rural 2007;37(1):241-246.

Baker M, Brake J, Mcdaniel GR. The relationship between body weight loss during an induced molt and postmolt egg production, egg weight, and shell quality in caged layers. Poultry Science 1983;62:409-413.

Bell DD, Kuney DR. Historical and current molting practices in the U.S. table egg industry. Poultry Science 2003;82:965-970.

Berry WD. The physiology of induced molt. Poultry Science 2003;82:971980

Biggs PE, Persia ME, Koelkebeck KW, Parsons CM. Further evaluation of nonfeed removal methods for molting programs. Poultry Science 2004;83:745-752.

Donalson LM, Kim WK, Herrera P, Woodward CL, Kubena LF, Nisbet DJ Ricke RC. Utilizing different ratios of alfalfa and layer ration for molt induction and performance in commercial laying hens. Poultry Science 2005;84:362-369.

Freitas ER, Sucupira FS, Quevedo Filho IB, Oliveira RFS, Alves FGC, Carmo ABR. Utilização do feno da folha da leucena em rações para indução de muda forçada em poedeiras comerciais. Revista Brasileira de Saúde e Produção Aninal 2011;12(4):1067-1076.

Garcia EA. Muda forçada em poedeiras comerciais e codornas. Anais da Conferência Apinco de Ciência e Tecnologia Avícolas; 2004; Santos, São Paulo. Brasil. p. 45-62.

Giampaulli J, Pedroso AA, Moraes VMB. Desempenho e qualidade de ovos de poedeiras após a muda forçada suplementadas com probiótico em diferentes fases de criação. Ciência Animal Brasileira 2005;6(3):179186.

Girardon JC. Métodos nutricionais de muda forçada em poedeiras semipesadas [dissertação]. Pelotas (RS): Universidade Federal de Pelotas; 2011.

Koelkebeck KW, Parsons CM, Leeper WR, Moshtaghina J. Effect of duration of fasting on postmolt laying hen performance. Poultry Science 1992:71(3):434-439.

Kwon YM, Kubena LF, Woodward CL, Byrd JA, Moore RW, Nisbet DJ, Ricke SC. Use of an alfalfa diet for molting in leghorn hens to reduce Salmonella enteritidis colonization and invasion. Poultry Science Poultry Science 2001;80(Suppl. 1):90 
Landers KL, Woodward CL, Li X, Kubena LF, Nisbet DJ, Ricke SC. Alfalfa as a single dietary source for molt induction in laying hens. Bioresource Technology 2005; 96:565- 570.

Meija L, Meyer ET, Utterback PL, Utterback CW, Parsons CM, Koelkebeck KW.

Evaluation of limit feeding corn and DDGS in non-feed-withdrawal molt programs for laying hens. Poultry Science 2010;89:386-392.

Moreng RE, Avens JS. Ciência e produção de aves. São Paulo: Roca; 1990

Onbasilar EE, Erol H. Effects of different forced molting methods on postmolt production, corticosterone level, and immune response to sheep red blood cells in laying hens. Journal Applied Poultry Research 2007;16(4):529-536.

Rostagno HS, Albino LFT, Donzele JL. Gomes PC, Oliveira RF de, Lopes DC, Ferreira AS, Barreto SL de T. Tabelas brasileiras para aves e suínos: composição de alimentos e exigências nutricionais. 3.ed. Viçosa: UFV; 2005

SAS Institute. SAS ${ }^{\circledR}$ user' ${ }^{\prime}$ guide: statistics. Cary, NC; 2002
Sibbald IR. Passage of feed through the adult rooster. Poultry Science 1979; 58:446-459

Sgavioli S. Desempenho de poedeiras comerciais submetidas à diferentes métodos de muda de penas sob diferentes temperaturas [dissertação] Jaboticabal (SP): Universidade Estadual Paulista; 2010.

Sgavioli S, Filardi RS, Praes M, Assuena V, Pileggi J, Andrade PC, Boleli IC Junqueira OM. Performance of layers submitted to different forcedmolting methods and different temperatures. Revista Brasileira de Ciência Avícola 2011; 13(3):207-210

Souza KMR, Carrijo AS, Allaman IB. Fascina VB, Mauad JRC, Suzuki, FM. Métodos alternativos de restrição alimentar na muda forçada de poedeiras comerciais. Revista Brasileira Zootecnia 2010;39(2):356-362.

Woodward CL, Kwon YM, Kubena FM, Byrd JA, Moore RW, Nisbet DJ, Rickes SC. Reduction of Salmonella enterica serovar Enteritidis colonization and invasion by an alfalfa diet during molt in Leghorn hens. Poultry Science 2005;84:185-193. 